\title{
Acute pancreatitis prevalence in children with cystic fibrosis and PIP score prediction applicability
}

\author{
Prevalența pancreatitei acute la copiii cu fibroză chistică și utilizarea \\ scorului PIP în predicția acesteia
}

Valentina-Daniela COMĂNICI ${ }^{1,2}$, loana Florentina CODREANU ${ }^{1,2}$, Anca BĂLĂNESCU $^{1}$, Alina Angelica BELIVACA ${ }^{1}$, lustina Violeta STAN ${ }^{1,2}$, Mihai CRAIU ${ }^{1,2}$, Mirela-Elena RITIVOIU ${ }^{1,2}$, Dumitru MATEI ${ }^{1,2}$

${ }^{1}$ UMF „Carol Davila“, București, România

${ }^{2}$ Departamentul Pediatrie INSMC „Alessandrescu Rusescu“, București, România

\begin{abstract}
One of the affected organs in cystic fibrosis $(C F)$ is the pancreas, mainly translated into exocrine pancreatic insufficiency. Although rare, acute pancreatitis (AP) has been described, mostly in pancreatic sufficient patients.

Objectives. Estimating AP prevalence in CF pediatric population of the I.N.S.M.C. "AlessandrescuRusescu" CF centre.

Material and methods. 5 year retrospective study (2011-2016) including INSMC CF centre pediatric population aged 3-18 years. PA diagnosis was established on the presence of minimum 2 criteria between: characteristic abdominal pain, $x 3$ normal value for age elevation of amylase/lipase, medical imaging evaluation suggestive for AP. Patients were evaluated with different criteria including PIP score of predicting AP risk.

Outcomes. 48 patients were included with a slight female predominance (54\%). 3 of them presented diagnostic criteria for AP (6,25\%), all heaving pancreatic insufficiency and high PIP score (low risk of developing AP); 2 of them have low compliance with pancreatic enzymes substitution therapy; one of them presented recurrent episodes of $A P$.

Conclusions. AP is a rare CF complication. It can be easily missed due to a large number of abdominal pain and emesis causes in CF patients. Although it is usually associated with pancreatic sufficiency, all our patients were pancreatic insufficient.
\end{abstract}

Keywords: cystic fibrosis, acute pancreatitis, PIP score

\section{REZUMAT}

Pancreasul este unul dintre organele afectate în cadrul fibrozei chistice, o bună parte dintre pacienți asociind insuficiență pancreatică exocrină. O alta complicație este pancreatita acută, considerată a fi rară și mai frecvent asociată cu suficiența pancreatică.

Obiective. Estimarea prevalenței PA în cadrul populației de pacienți pediatrici cu FC aflați în evidența I.N.S.M.C. "Alessandrescu-Rusescu“. 
Material și metode. Studiu retrospectiv cu durată de 5 ani (2011-2016) ce a inclus pacienții aflați în evidența INSMC cu diagnosticul de FC și vârstă între 3 și 18 ani. Diagnosticul de PA a fost stabilit pe prezența a minimum 2 criterii dintre: durere abdominală caracteristică, creșterea valorilor amilazei/lipazei $x 3$ valoarea normală pentru vârsta $(V N)$, imagistică sugestivă pentru PA. Pentru evaluarea pacienților au fost luate în calcul mai multe variabile printre care și scorul PIP de predicție a riscului de a dezvolta PA.

Rezultate. Au fost incluși în studiu 48 de pacienți cu ușoară predominanță a fetelor (54\%). Dintre aceștia, 3 băieți au întrunit criteriile de diagnostic pentru PA (6,25\%), toți cu insuficiență pancreatică și cu scor PIP inalt (risc teoretic scăzut pentru a dezvolta PA); 2 dintre aceștia cu complianță scăzută la terapia de substituție cu enzime pancreatice; unul dintre pacienți a prezentat 3 episoade de PA, ceilalți doi episod unic.

Concluzii. PA este o complicație rară în cadrul FC. Ea poate fi omisă ușor întrucât există numeroase cauze de dureri abdominale și vărsături la pacientul cu fibroză chistică. Deși este mai frecvent asociată cu suficiență pancreatică, cei trei pacienți cu PA din studiul nostru prezintă insuficiență pancreatică.

Cuvinte cheie: fibroză chistică, pancreatită acută, scor PIP

\author{
Abrevieri \\ FC - fibroză chistică \\ PA - pancreatită acută \\ PAR - pancreatită acută recurentă \\ $\mathrm{PCR}$ - polymerase chain reaction \\ INSMC - I.N.S.M.C. „Alessandrescu-Rusescu“ \\ IP - insuficiență pancreatică
}

\author{
SP - suficiență pancreatică \\ CFTR - cystic fibrosis transmembrane conductance regulator \\ IMC - indice de masă corporală \\ TS - testul sudorii \\ PERT - terapia de substituție cu enzime pancreatice
}

\section{INTRODUCERE}

Pancreatita este o inflamație a pancreasului și poate îmbrăca două forme: acută și cronică (1). Etiologia PA la populația pediatrică diferă de cea de la adult, fiind dominată de cea medicamentoasă și biliară, însă fibroza chistică este recunoscută drept cauză la $2 \%$ dintre pacienți (2).

Prevalența PA în populația generală pediatrică este între 3,6 și 13,2/100.000 (3), însă în cadrul FC este mult mai crescută și în funcție de statusul pancreasului exocrin întâlnim raportări de $1-2 \%$ la pacienții cu insuficiență pancreatică mergând până la 15-20\% (4) la cei cu suficiență pancreatică. De notat este faptul că cei mai mulți dintre pacienții cu FC se regăsesc în prima categorie și manifestă un fenotip de insuficiență pancreatică având mutații severe pe ambele alele, în timp ce pacienții cu suficiență pancreatică prezintă mutații mai blânde.

Când apare un episod simptomatic, există o perturbare a balanței între gradul de rezervă pancreatică acinară și severitatea obstrucției ductale, ele fiind invers proporționale cu gradul de disfuncție al CFTR (5). Simptomatologia este, de cele mai multe ori, reprezentată de dureri abdominale însoțite sau nu de vărsături (6), acuze frecvent întalnite la pacientul cu FC, putând astfel să fie trecută cu vederea.

Prin acest studiu ne-am dorit sa estimăm prevalența PA în cadrul populației de pacienți pediatrici cu FC aflați în evidența INSMC.

\section{MATERIALE ŞI METODE}

Pentru verificarea ipotezei de lucru și atingerea obiectivului, am implementat un studiu cu design retrospectiv desfășurat pe o perioadă de 5 ani (20112016). S-au utilizat informațiile arhivate în foile de observație generală sau preluate din sistemul informatic (Hipocrate) al INSMC ale tuturor pacienților diagnosticați cu FC în perioada de timp aleasă (1 ianuarie 2011-31 decembrie 2016).

Astfel, căutând în arhivă/interogând baza de date a sistemului informatic după codurile de diagnostic E84.0 (FC cu manifestări pulmonare), E84.1 (FC cu manifestări intestinale), E84.8 (FC cu alte manifestări), E84.9 (FC, nespecificată), a rezultat un număr de 68 de pacienți cu FC. Alt criteriu de includere luat în considerare în afara obligativității diagnosticului de FC a fost cel legat de vârstă, fiind incluși în acest studiu exclusiv pacienții cu vârstă peste 3 ani. Astfel, excluzând pacienții cu vârsta mai mică de 3 ani din cohorta de 68 de pacienți cu FC identificați între 2011 și 2016, am selecționat pentru analiza datelor doar 48 de pacienți cu FC și vârstă cuprinsă între 3 și 18 ani.

Diagnosticul de FC a fost stabilit în cadrul cohortei de pacienți conform consensurilor internaționale aflate în vigoare $(7,8)$, plecând de la semne si simptome clinice sugestive pentru FC coroborate cu testare pozitivă la iontoforeza cu pilocarpină (valori peste $60 \mathrm{mEq} / \mathrm{l}$ ale clorului în sudoare) și/sau identificare de mutații genetice ale CFTR la nivelul ambelor alele, cunoscute a fi 
cauzatoare de boală. Pentru identificarea genotipului s-a efectuat testare moleculară prin PCR în Centrul Regional de Genetică Medicală (CRGM) București integrat în structura INSMC, utilizând un panel (CF genetic Assay Nuclear Laser Medicine genotyping kit furnizat de Nuclear Laser Medicine, Settala, Italia) de 38 mutații si 1 polimorfism la nivelul genei CFTR (F508del (delta F508), I507del, F508C.I502T, 1706del17, 1677delTA, G542X, 1717-1G>A，R553X, Q552X, G551D， S549R(A>C), N1303K, 4016insT, R1162X, R1158X, W1282X, G1244E, 2789+5G>A, 711+1G>T, G85E, 3849+10kbC $>T$, 621+1G>T, R117H, D1152H, L1065P, R1066H, L1077P, 4382delA, 1259insA, 852del22, R347P, T338I, S912X, I148T, 3199del6, Allele 5T-7T-9T).

Pancreatita acută a fost definită prin îndeplinirea a minimum 2 dintre următoarele criterii: durere abdominală caracteristică pentru pancreatita acută, valori crescute ale amilazelor/lipazei serice de minimum $3 \mathrm{x}$ normalul pentru vârstă, semne imagistice sugestive pentru PA (edem, hemoragie sau necroză pancreatică). Totodată, existența unui episod de pancreatită acută atribuibilă oricărei alte etiologii a constituit criteriu de excludere. Statusul de „suficiență pancreatică” a fost definit pe baza măsurării elastazei fecale atunci când valorile acesteia erau > $200 \mathrm{mcg} / \mathrm{g}$ fecale (determinată în afara unui episod de PA) (9).

Pentru toți cei 48 de pacienți cu FC selecționați au fost identificate și monitorizate o serie de variabile numerice continue sau ordinale după cum urmează: variabile demografice - vârstă, gen; variabile clinice - dure- re abdominală „în bară“, prezența și numărul vărsăturilor, recurența episoadelor de PA, existența și numărul exacerbărilor pulmonare, statusul infecției cronice cu Pseudomonas aeruginosa; variabile antropometrice - valoarea IMC; variabile biochimice - valoarea amilazei serice $>170 \mathrm{UI} / \mathrm{I}$, valoarea glicemiei à jeun, valoarea transaminazelor serice, valoarea elastazei fecale, valoarea testului sudorii la momentul diagnosticului exprimat în mEq Cl în sudoare; mutația CFTR identificată; valoarea scorului PIP; complianța la terapia de substituție enzimatică.

Datele au fost ulterior exprimate ca medie și deviație standard. Variabilele nominale au fost prezentate sub formă de procente. Analiza statistică s-a făcut utilizând softul SPSS versiunea 16 pentru Windows.

\section{REZULTATE}

Au fost incluși în studiu 48 de pacienți, dintre care 26 fete (54\%). Vârsta medie a fetelor incluse în studiu a fost de 8,42 ani (DS 3,93) (fig. 1), similară cu vârsta medie a băieților incluși în studiu: 8,86 ani (DS 3,59) (fig. 2).

Dintre toți cei 48 de pacienți incluși în studiu, numai 3 pacienți au întrunit criteriile pentru stabilirea diagnosticului de pancreatită acută, stabilind astfel prevalența PA la 6,25\% în lotul nostru de studiu. Toți pacienții cu FC si PA au fost băieți și toți aveau insuficiență pancreatică. Reținem că doar 1 pacient din 3 a avut episoade de pancreatită recurentă. Doi dintre cei trei pacienți cu PA asociau complianță scăzută la

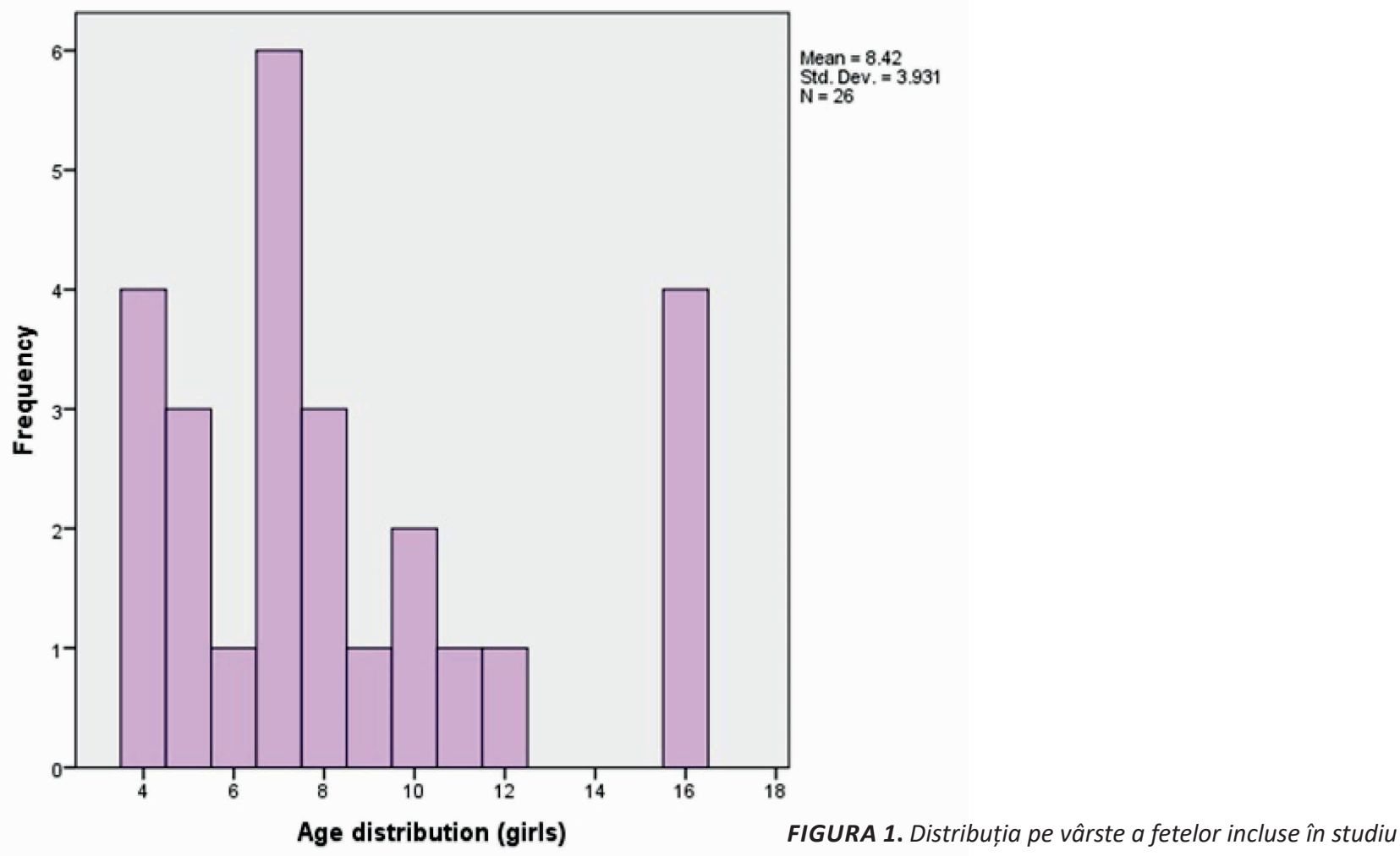




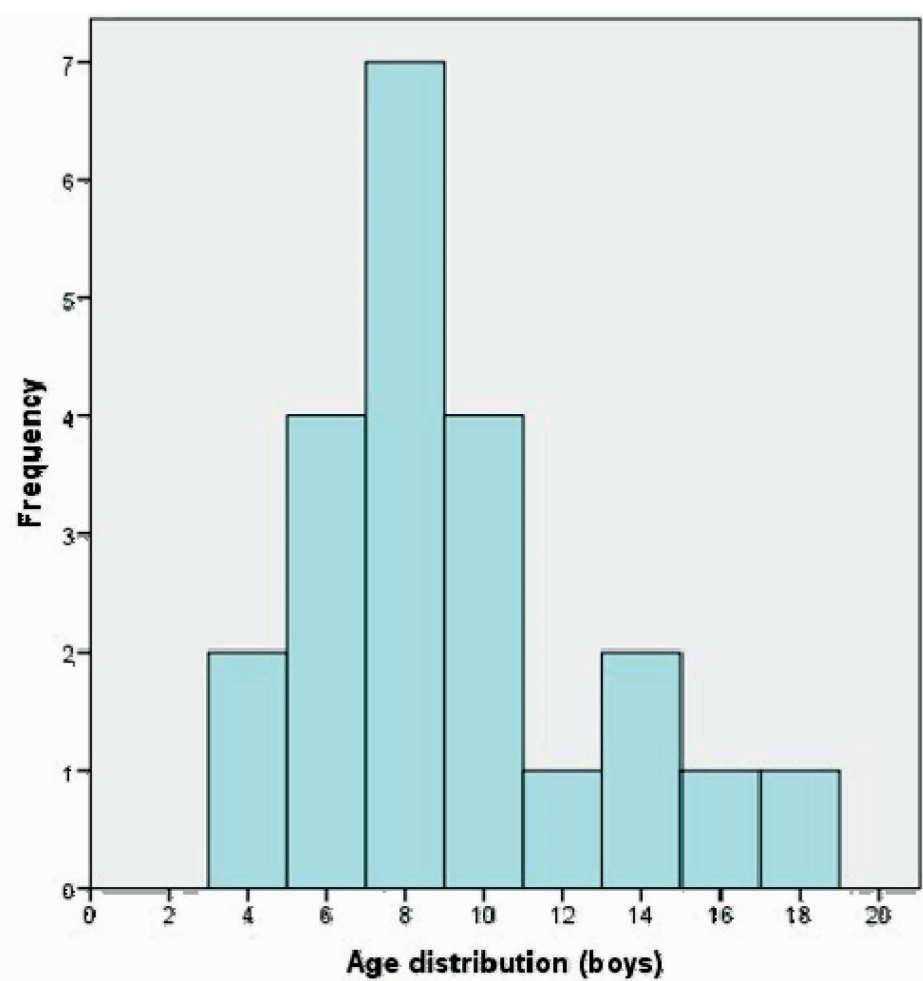

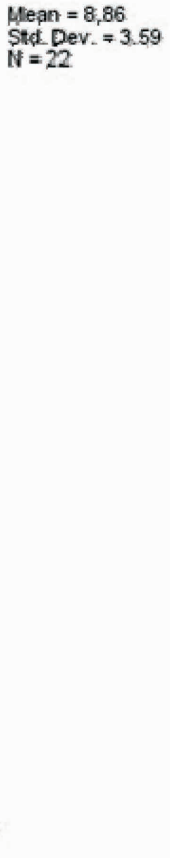

FIGURA 2. Distribuția pe vârste a băieților incluși în studiu
PERT. Niciun pacient dintre cei trei cu PA nu a asociat hiperglicemie și/sau hipertransaminazemie.

Caracteristicile celor 3 pacienți identificați cu PA sunt prezentate în Tabelul 1.

\section{DISCUŢII}

Pancreatita acută este definită ca inflamația acută pancreatică limitată la un episod singular (PA) sau recu- rent (PAR), iar diagnosticul se bazează pe prezența a minimum 2 dintre următoarele simptome: durere abdominală („în bară“), triplări ale valorilor amilazelor și lipazelor serice, precum și prezența modificărilor imagistice sugestive. Etiologia PA este complexă și diferă în populația pediatrică față de cea adultă, FC fiind considerată cauza a doar $2 \%$ dintre PA copilului (2)

În prezent, este unanim acceptat și cunoscut de aproximativ 2 decenii substratul genetic responsabil de

TABEL 1. Caracteristicile pacienților cu pancreatită acută și fibroză chistică identificați în studiu

\begin{tabular}{|c|c|c|c|}
\hline & $\mathrm{P} 1-\mathrm{CC}$ & P2-DC & P3 - TA \\
\hline Vârstă (ani) & 6 & 8 & 13 \\
\hline Gen & $\hat{0}$ & $\hat{0}$ & $\hat{0}$ \\
\hline Genotip & G85E/S549N & F508del/F508del & F508del/F508del \\
\hline (PIP score) & $(0,73)$ & $(0,96)$ & $(0,96)$ \\
\hline Testul sudorii & $84 \mathrm{mEq} / \mathrm{Na}$ & $106 \mathrm{mEq} / \mathrm{Na}$ & $116 \mathrm{mEq} / \mathrm{Na}$ \\
\hline $\begin{array}{l}\text { Elastaza pancreatică fecală } \\
\text { (VN > 200 } \mu \mathrm{g} / \mathrm{g} \text { ) }\end{array}$ & $80 \mu \mathrm{g} / \mathrm{g}$ & $100 \mu \mathrm{g} / \mathrm{g}$ & $120 \mu \mathrm{g} / \mathrm{g}$ \\
\hline Simptome & $\begin{array}{l}\text { Vărsături, durere abdominală } \\
\text { „în bară“, diaree }\end{array}$ & $\begin{array}{l}\text { Vărsături, durere abdominală } \\
\text { „în bară“ }\end{array}$ & $\begin{array}{l}\text { Vărsături, durere abdominală } \\
\text { difuză, diaree, tuse productivă }\end{array}$ \\
\hline IMC (kg/mp) & 17,3 (P85\%) & $18,04(\mathrm{P} 75 \%)$ & 17,8 (P30\%) \\
\hline Patologie asociată & $\begin{array}{c}\text { Exacerbare pulmonară, infecție } \\
\text { cronică cu Pseudomonas } \\
\text { aeruginosa, complianță } \\
\text { scazută PERT, caz social }\end{array}$ & $\begin{array}{l}\text { Exacerbare pulmonară (virală), } \\
\text { complianță scăzută PERT }\end{array}$ & $\begin{array}{l}\text { Exacerbare pulmonară, infecție } \\
\text { cronică Pseudomonas aeruginosa, } \\
\text { enterită cu Campylobacter }\end{array}$ \\
\hline Amilaza serică (UI/I) & 421 & 986 & 236 \\
\hline Glicemie (mg/dl) & 80 & 100 & 100 \\
\hline AST/ALT (U/I) & $36 / 28$ & $17 / 11$ & $25 / 39$ \\
\hline Recurență & + & - & - \\
\hline
\end{tabular}

P1 - pacientul 1, P2- pacientul 2, P3 - pacientul 3, CC/DC/TA - inițialele pacienților cu pancreatită acută, VN - valoare normală, $P E R T$ - pancreatic enzyme replacement therapy/terapie de substituție enzimatică 
apariția episoadelor recurente de PA. Cele mai frecvente gene care suferă mutații implicate în etiologia PA(R) sunt gena carboxipeptidazei A1, PRSS1, SPINK1, CTRC, CFTR, CLDN2, CASR, CEL-MODY, CPA1 (2). În ceea ce privește persoanele cu mutații compuse heterozigote ale CFTR + SPINK/PRSS1/CTRC, acestea au un risc mai mare de 40x față de populația generală în a dezvolta PA. În cazul particular al pacienților cu FC, aceștia pot fi grosier împărțiți în pacienți cu Insuficiență pancreatică (IP) și pacienți cu suficiență pancreatică (SP) adică aceia care au o elastază fecală pancreatică $>200 \mathrm{mcg} / \mathrm{g}$. Cu toate acestea, unii autori consideră diagnosticul de certitudine al IP abia la o valoare a elastazei fecale sub pragul de $100 \mathrm{mcg} / \mathrm{g}$, orice rezultat cuprins în intervalul 100-200 mcg/g fiind indeterminat și greu de interpretat. Această ipoteză vine din explicarea instalării graduale a insuficienței pancreatice, dihotomizarea certă în două categorii (suficient/ insuficient) fiind mai degrabă scolastică decât reală fiziopatologic (10).

Prevalența PA este considerată scăzută în rândul pacienților cu FC, chiar dacă gena responsabilă de boală este implicată în etiologia PA în populația generală. Astfel, prevalența PA la pacienții cu FC și SP este de circa $20 \%$ în timp ce în rândul celor cu FC și IP de doar 1-2\%, aceștia din urmă constituind majoritatea pacienților cu FC. Explicația acestei rare întâlniri a PA la cei cu IP rezidă în faptul că este necesară existența unei mase critice acinare pentru dezvoltarea simptomatologiei, deci cei cu FC și SP au risc mai înalt (2).

Pentru estimarea riscului dezvoltării PA la un pacient cu FC există o serie de instrumente elaborate în scopul de a veni în ajutorul clinicianului. Un astfel de instrument este scorul PIP (pancreatic insufficiency prevalence score). Acesta este un scor de prevalență a IP care evaluează corelarea genotip-fenotip și ajută în predicția riscului PA la subiecții cu FC în funcție de genotip. Un scor PIP $<0,25$ semnifică risc înalt de apariție a PA. Conform acestui instrument de predicție validat în populația cu FC, anumite genotipuri CFTR se asociază mai frecvent cu PA, mai ales genotipurile cu manifestări mai blânde ale FC având risc mai mare de a dezvolta pancreatită la un moment dat (11).

Importanța estimării riscului de PA la copilul cu FC vine și pe fondul lipsei ghidurilor specifice dedicate acestora. Existența acestor ghiduri ar permite eficientizarea tratamentului, mai ales în condițiile în care tratamentul nu este echivalent cu cel al adultului și necesită atenție deosebită asupra intervenției nutriționale la pacientul pediatric (5).

Prevalența regasită în cadrul studiului nostru este de 6,25\%, o prevalență crescută având în vedere faptul că cei 3 pacienți cu minim 1 episod de pancreatită au un scor PIP crescut. Ei prezintă mutații cunoscute a fi asociate cu fenotipuri severe, de clasa II și III (12), și în concluzie un risc teoretic scăzut pentru a dezvolta PA.
Identificarea PA în lotul nostru de pacienți cu FC care asociază scor PIP sugestiv pentru risc scăzut poate avea o explicație speculativă în faptul că valorile elastazei fecale în cele doua cazuri de homozigoți delta F 508 nu se situau în zona de insuficență pancreatică severă, valorile fiind > $100 \mathrm{mcg} / \mathrm{g}$, dar sub cele $200 \mathrm{mcg} / \mathrm{g}$ necesare definiției IP. Astfel, putem bănui o rezervă acinară minimă dar suficientă pentru declanșarea unui episod de PA. Terlizzi și colab. recomandă screening activ pentru PA la un PIP score $<0,25$. Vârsta de apariție este mică pentru două dintre cazurile raportate, momentul apariției episoadelor de PA fiind mai frecvent la adolescență și maturitate (13). Nu au fost identificate medicamente care să fi precipitat episoadele de PA, deși ele s-au suprapus peste episoade de exacerbări pulmonare, pacienții nu au primit medicație care să fi fost anterior incriminată în PA de tipul minociclinei/ tygeciclinei (14). Deși au fost descrise cazuri de PA medicamentoasă indusă de cimetidina/ ranitidina/ omeprazol (15) nu am găsit raportări la pacienți cu FC, cunoscută fiind asocierea antiacidelor, dar mai ales a inhibitorilor de pompă de protoni la PERT, regasită și în schema de tratament a pacienților noștrii.

În era potențiatorilor, sunt de urmărit efectele acestora în cazul pacienților cu pancreatită recurentă, datele din literatură prezentând o reducere a episoadelor (16).

Determinismul genetic al pancreatitelor nu se oprește la mutațiile genei CFTR ci au fost studiate mutații ale genelor PRSS1, SPINK1, CTRC si CASR corelate cu PA si PR $(17,18)$ însă sunt date care sugerează că și factorii epigenetici pot fi implicați (19). Într-un studiu care evaluează transheterozigoția la 48 de pacienți cu FC și episoade de PA, 35 de pacienți cu FC dar fără PA și lot control cu subiecți sănătoși, a evidențiat că 14 dintre cei cu FC si AP versus 2 cu FC dar fără AP și 3 din lotul control prezentau mutații ale genelor implicate în activarea intrapancreatică a tripsinei (20), pacienții din lot prezentând și mutații de clasa II și III cu IP. Având în vedere caracteristicile lotului nostru de pacienți o asemenea explicație ar fi plauzibilă însă nu se justifică testarea în acest moment, mai ales pentru pacienții cu episod unic de PA din considerente de cost-eficiență.

\section{Limitări ale studiului}

Menționăm că există anumite limitări ale studiului de față, precum designul retrospectiv, dar și caracterul monocentric, ceea ce a stat la baza numărului mic de subiecți ai lotului de studiu, pe fondul definiției FC de boală genetică rară. Cu toate acestea, având în vedere particularitatea de prevalență scăzută a bolii cercetate (PA în populația pediatrică cu FC), considerăm valide concluziile ce urmează a fi expuse și subliniem necesitatea verificării acestora în studii viitoare, prospective, randomizate. 


\section{CONCLUZII}

Pancreatita acută (PA) este o complicație rară în cadrul pacienților cu FC. Considerând populația de pacienți cu FC ca fiind compusă din indivizi cu suficiență pancreatică (SP) + scor PIP scăzut (risc mare PA) și indivizi cu insuficiență pancreatică (IP) + scor PIP înalt (risc mic PA) și cunoscând rata prevalenței PA de aproximativ 20\% în rândul celor cu SP și de doar 1-2\% an rândul celor cu IP, putem concluziona că în lotul evaluat în acest studiu original, prevalența PA observată de 6,25\% este una înaltă. Particularitatea observată în lotul nostru de studiu constă în faptul că cei 3 pacienți cu FC și PA aveau IP și asociau teoretic risc scăzut de PA conform scorului PIP, aceasta fiind prima raportare de acest gen în literatura de specialitate. Cu toate acestea, nivelul elastazei pancreatice fecale nu era in zona de insuficiență pancreatică exocrină severă fiind cuprinsă în intervalul $100-200 \mathrm{mcg} / \mathrm{g}$.

Plecând de la observațiile de mai sus, sugerăm și subliniem importanța verificării criteriilor de diagnostic pentru PA în cazul copiilor cu FC care acuză dureri abdominale caracteristice „„̂n bară“, la care nu este identificată o altă cauză, chiar și în condițiile unui scor PIP înalt, dar la care nivelul elastazei fecale se menține în intervalul $100-200 \mathrm{mcg} / \mathrm{g}$. Atragem atenția că PA poate fi omisă ușor întrucât există numeroase cauze de dureri abdominale și vărsături la pacientul cu FC.

\section{Notă}

Această lucrare face parte din studiile doctorale desfășurate de către autorul principal la UMF "Carol Davila“, București, România.

Conflict of interest: none declared Financial support: none declared

\section{BIBLIOGRAFIE}

1. Srinath $\mathrm{Al}$, Lowe ME. Pediatric pancreatitis. Pediatr Rev. 2013 Feb;34(2):79-90.

2. Taylor CJ, Chen K, Horvath K, Hughes D, Lowe ME, Mehta D, Orabi Al, Screws J, Thomson M, Van Biervliet S, Verkade HJ, Husain SZ, Wilschanski M. ESPGHAN and NASPGHAN Report on the Assessment of Exocrine Pancreatic Function and Pancreatitis in Children. J Pediatr Gastroenterol Nutr. 2015 Jul;61(1):144-53.

3. Grzybowska-Chlebowczyk U, Jasielska M, Flak-Wancerz A, Więcek S, Gruszczyńska K, Chlebowczyk W, Woś H. Acute pancreatitis in children. Prz Gastroenterol. 2018;13(1):69-75.

4. Ooi CY, Dorfman R, Cipolli M, Gonska T, Castellani C, Keenan K, Freedman SD, Zielenski J, Berthiaume Y, Corey M, Schibli $\mathrm{S}$, Tullis E, Durie PR. Type of CFTR mutation determines risk of pancreatitis in patients with cystic fibrosis. Gastroenterology. 2011 Jan;140(1):153-61.

5. Freeman AJ, Ooi CY. Pancreatitis and pancreatic cystosis in Cystic Fibrosis. J Cyst Fibros. 2017 Nov; 16 Suppl 2:S79-S86.

6. Castellani C, Duff AJA, Bell SC, Heijerman HGM, Munck A, Ratjen F, Sermet-Gaudelus I, Southern KW, Barben J, Flume PA, et al. ECFS best practice guidelines: the 2018 revision. J Cyst Fibros. 2018 Mar; 17(2):153-178.

7. Balfour -Lynn I. Clinical Guidelines: Care of Children with Cystic fibrosis 7th edition. Royal Brompton Hospital and NHS. 2017.
8. Villanueva G, Marceniuk G, Murphy MS, Walshaw M, Cosulich R; Guideline Committee. Diagnosis and management of cystic fibrosis: summary of NICE guidance. BMJ. 2017 Oct 26;359:j4574.

9. Terlizzi V, Tosco A, Tomaiuolo R, Sepe A, Amato N, Casale A, Mercogliano C, De Gregorio F, Improta F, Elce A, Castaldo G, Raia V. Prediction of acute pancreatitis risk based on PIP score in children with cystic fibrosis. J Cyst Fibros. 2014 Sep; 13(5):579-84.

10. Struyvenberg MR, Martin CR, Freedman SD. Practical guide to exocrine pancreatic insufficiency - Breaking the myths. BMC Med. 2017 Feb 10;15(1):29.

11. Ooi CY, Durie PR. Cystic fibrosis transmembrane conductance regulator (CFTR) gene mutations in pancreatitis. J Cyst Fibros. 2012 Sep;11(5):355-62.

12. Ahmed N, Corey M, Forstner G, Zielenski J, Tsui LC, Ellis L, Tullis E, Durie P. Molecular consequences of cystic fibrosis transmembrane regulator (CFTR) gene mutations in the exocrine pancreas. Gut. 2003 Aug;52(8):1159-64.

13. Turner M, Jackson H, Harle R, Bohmer R, Reid DW. Atypical presentation of acute pancreatitis in a man with pancreatic insufficiency and cystic fibrosis: a case report. J Med Case Rep. 2010 Aug 18;4:275.

14. Alhaddad O, Elsabaawy M, Elfauomy M, Elsabaawy D, Mansour T. Updates in drug-induced acute pancreatitis. Egyptian Liver Journal. 2020; 10:49
15. Youssef SS, Iskandar SB, Scruggs J, Roy TM. Acute pancreatitis associated with omeprazole. Int J Clin Pharmacol Ther. 2005 Dec;43(12):558-61.

16. Carrion A, Borowitz DS, Freedman SD, Siracusa CM, Goralski JL, Hadjiliadis D, Srinivasan S, Stokes DC. Reduction of Recurrence Risk of Pancreatitis in Cystic Fibrosis With Ivacaftor: Case Series. J Pediatr Gastroenterol Nutr. 2018 Mar;66(3):451-454.

17. LaRusch J, Whitcomb DC. Genetics of pancreatitis. Curr Opin Gastroenterol. 2011 Sep;27(5):467-74.

18. Muller N, Sarantitis I, Rouanet M, de Mestier L, Halloran C, Greenhalf W, Férec C, Masson E, Ruszniewski P, Lévy P, Neoptolemos J, Buscail L, Rebours V. Natural history of SPINK1 germline mutation related-pancreatitis. EBioMedicine. 2019 Oct;48:581-591.

19. Sandoval J, Pereda J, Pérez S, Finamor I, Vallet-Sánchez A, Rodríguez JL, Franco L, Sastre J, López-Rodas G. Epigenetic Regulation of Early- and Late-Response Genes in Acute Pancreatitis. J Immunol. 2016 Nov 15;197(10):4137-4150.

20. Sofia VM, Surace C, Terlizzi V, Da Sacco L, Alghisi F, Angiolillo A, Braggion C, Cirilli N, Colombo C, et al. Trans-heterozygosity for mutations enhances the risk of recurrent/ chronic pancreatitis in patients with Cystic Fibrosis. Mol Med. 2018 Jul 27;24(1):38. 